\title{
Gluten-free biscuits produced from new drought tolerant corn hybrids: processing and evaluation
}

\author{
Ahmed M. Hussein ${ }^{1}$, Attia A. Yaseen ${ }^{1}$, Ramadan M. Esmail ${ }^{2}$ and Ayman A. Mohammad ${ }^{1 *}$
}

\begin{abstract}
Background: Drought tolerance and grain quality are the main challenges in maize cultivation due to climatic changes and population growth. So, this study aims to evaluate the suitability of nixtamalized corn flour (NCF) obtained from new drought-tolerant white corn hybrids planted under drought conditions for gluten-free biscuits production. Chemical compositions of corn hybrids, pasting properties of dough, and physical and sensory characteristics of biscuits were evaluated.

Results: Protein, fat, crude fiber, and ash contents of corn hybrids differed significantly, while there were no significant differences between carbohydrate contents. NCF showed lower peak viscosity, trough value, breakdown, and final and setback viscosities as compared to raw Single Cross Giza (SC 10) flour. This indicates that nixtamalization process reduced retrogradation capability of the produced corn flours. Corn flour with the lowest retrogradation tendency was the one produced from genotype No. 5. Baking quality, sensory properties, and color attributes indicated that biscuits made from NCF of hybrids No. 2 and 5 were significantly more acceptable compared to other samples.

Conclusion: Gluten-free biscuits could be produced using NCF of all white hybrids with acceptable quality. Moreover, superior sensory characteristics of samples manufactured from genotypes No. 2 and 5 and thereby suitable for gluten-hypersensitive patients.
\end{abstract}

Keywords: Corn flour, Biscuits, Nixtamalization, Gluten-free, Celiac disease

\section{Background}

Celiac disease $(\mathrm{CD})$ is a food-induced disease triggered by consuming cereal prolamines named gliadins (in wheat), secalins (in rye), hordeins (in barley), or avenins (in oat) (Padalino et al. 2016). These proteins resist the digestion in the gastrointestinal due to the presence of multiple proline-glutamine residues and most of them are exposed to deamination by tissue transglutaminase. So, ingestion of these proteins damaged the finger-like villi of small intestine. In this case, the body became unable to absorb nutrients into the bloodstream, causing the main nourishment (Bernardo and Pena 2012). At present, gluten-free diet is the only remediation way to prevent its symptoms. Corn, rice, potato, and other

\footnotetext{
* Correspondence: aymnmohamed79@yahoo.com

${ }^{1}$ Food Technology Department, National Research Centre, 33 Bohouth St.,

Dokki, Cairo, Egypt

Full list of author information is available at the end of the article
}

tubers, the main gluten-free sources, cannot represent the technological requirements for bakery processing. The viscoelastic properties of these flours depend on the starch component more than proteins component which are not able to form a network (Padalino et al. 2016). To develop gluten-free products, professionals are always exploring the abilities of different food ingredients/crops as well as adequate technological processes (Padalino et al. 2011).

Maize (Zea mays L.) is the second carbohydrate source after wheat in Egyptian foods. However, in native form, its technological properties limited its utilization. Nixtamalization (alkaline cooking) is one of the technological approaches used for production of hydrated tortilla dough (masa) with convenient and functional properties, where the crystalline starch macromolecules converted into amorphous material able to produce a malleable product (Gomez et al. 1991). From the nutritional point 
of view, nixtamalization process fragile the kernel pericarp, enhances both protein content and quality, increases the content and availability of calcium and niacin, and lowers the insoluble dietary fiber content (Chavez-Santoscoy et al. 2016; Perez-Carrillo et al. 2017). Moreover, Perez-Carrillo et al. (2017) reported that gluten-free cookies manufactured using NFC fortified with crosslinked modified starch had 65\% more dietary fiber, softer texture, and the best sensory acceptance in every evaluated parameter even when compared to those manufactured using wheat flour.

On the other hand, the demand for maize in developing countries will rise against both wheat and rice by 2020 , while by 2025 maize will be the greatest crop produced all over the world. Moreover, in African countries, consumption of wheat in 2009 was $50.0 \mathrm{~kg}$ per capita in contrast to $42 \mathrm{~kg}$ of maize (FAO 2009). Furthermore, production of maize is 55\% more than that of wheat which suggests that African countries should increase consumption of maize varieties that can be produced and developed in Africa. But maize cultivation is challenged by both drought tolerance and grain yield especially under the climatic changes (Ignjatovic-Micic et al. 2014). So, the main objective of all plant breeders is to produce varieties with improved yield and quality characteristics that attracts the farmers or other end users such as food industry (Esmail et al. 2015, 2016).

According to our results obtained from field evaluation conditions, the best superior six hybrid of white corn were selected based on its performance for grain yield. The selected hybrids were used to produce nixtamalized corn flour (NCF), which were utilized in glutenfree biscuits production. Chemical composition of grains, dough rheological properties of NCF, color attributes, baking quality, and organoleptic characteristics of the produced biscuits were studied.

\section{Materials and methods}

\section{Raw materials}

The corn hybrids used in this study is the best of six white maize crosses selected according to their superiority in grain yield assessed in the field experiment and the commercial hybrid Single Cross Giza 10 as a control hybrid. These hybrids were obtained from hybridization between parental inbred lines imported from The International Maize and Wheat Improvement Center (CIMMYET). These hybrids were planted under normal and drought conditions in the Experimental Farm of Agric. Res. Center (ARC), Delta region, EL-Kalyubia Governorate, Egypt. Sucrose, shortening, sun flower oil, salt, sodium, and ammonium bicarbonate were purchased from local market, Dokki, Egypt.

\section{Chemical composition}

Moisture, protein, ash, fiber, and fat contents of corn hybrids were determined according to AOAC (2005). Total carbohydrates were calculated by difference.

\section{Preparation of NCF}

The traditional cooking method was used to prepare NFC according to Vidal-Quintanar et al. (2001) with some modification as follows: The whole corn grains (1 $\mathrm{kg}$ ) were soaked in $3 \mathrm{~L}$ of $1 \%$ calcium hydroxide solution then cooked at $95{ }^{\circ} \mathrm{C}$ for $95 \mathrm{~min}$. The nixtamal was steeped for about $15 \mathrm{~h}$ at room temperature then washed with excess water (three times) followed by decantation using a sieve. The wet masa was dried in an air oven at $85{ }^{\circ} \mathrm{C}$ for about $6 \mathrm{~h}$. The dry masa was ground using Brabender mill to pass through a 60 mesh screen. The prepared masa were packed in polyethylene bags and stored in a refrigerator until used.

\section{Pasting properties of corn flours}

Pasting properties of NCF and raw Single Cross Giza 10 (SC10) flour were determined using a rapid visco analyser (RVA) starch master R\&D pack V 3.0 (Newport Scientific Narrabeen, Australia) according to AACC (2000). The RVA parameters measured were peak time, peak viscosity, trough viscosity, final viscosity, break down viscosity, and set back.

\section{Preparation of biscuits}

Biscuit was manufactured using the standard procedure (AACC 2000) as follows: NCF (100 g), sugar (30 g), shortening $(15 \mathrm{~g})$, sodium bicarbonate $(1.11 \mathrm{~g})$, salt $(0.93$ $\mathrm{g})$, dextrose solution $(14.66 \mathrm{ml})$, and the required water. All dry ingredients were mixed together then all liquid ingredients were added to the dry mixture and mixed in a dough mixer at low speed for $3 \mathrm{~min}$. The water, required to obtain smooth dough, was added and the obtained dough was left to rest for $5 \mathrm{~min}$. Dough was sheeted to 3-mm thickness then cut to circle pieces using templates with an outer diameter of $50 \mathrm{~mm}$. The biscuits were baked at $180{ }^{\circ} \mathrm{C}$ for $12 \mathrm{~min}$, and allowed to cool at room temperature for $1 \mathrm{~h}$. Raw SC 10 flour was used to prepare the control sample.

\section{Evaluation of biscuits}

Diameter and thickness of biscuits were recorded and spread ratio was calculated. Organoleptic properties (color, flavor, taste, texture, appearance, and overall acceptability) of biscuits were evaluated according to Hoojjat and Zabik (1984) by ten panelists from the staff of Food Technology Department, National Research Centre, Cairo. Samples were served to the panelists and they were asked to assign scores from 0 to 10 for each parameter. 


\section{Color attributes of processed biscuits}

The color parameter were evaluated using Hunter, Lab Scan XE, Reston VA., calibrated with a white standard tile of Hunter Lab color standard (LX No. 16379) $x=77.26, y$ $=81.94$, and $z=88.14\left(L^{*}=92.43, a^{*}=-0.88, b^{*}=0.21\right)$. The results were expressed in accordance with the CIELAB system where $L^{*}(L=0$ [black], $L=100$ [white]), $a^{*}$ ( $-a=$ greenness, $+a=$ redness $), b^{*}(-b=$ blueness,$+b$ $=$ yellowness).

\section{Statistical analysis}

All samples were analyzed in triplicates, except pasting properties $(n=1)$ and sensory evaluation $(n=10)$. The obtained data were subjected to one way analysis of variance (ANOVA) and the differences among the means were evaluated for significant at $5 \%$ level using the least significant difference test (LSD). Statistical analysis was carried out using the SAS Systems for Windows software, version 6.12 TS020 (SAS, Statistical Analysis System, Institute Inc., Cary, NC, 1996).

\section{Results}

\section{Chemical composition of corn hybrids}

The results of chemical analysis of the investigated corn grains planted under normal and water stress conditions are shown in Table 1 . The results indicated significant genotype differences $(p>0.05)$ for protein, fat, ash, and fiber contents. There were no significant differences in carbohydrate content between corn genotypes planted in normal and drought conditions. For instance, protein content showed wide range being $10.39 \%$ for genotype No.6 planted under drought condition and reached $12.11 \%$ for genotype No. 4 planted under the same condition. Other genotypes displayed intermediate value. Besides, protein content was also significantly influenced by drought condition, and it was significantly increased in some genotypes under water stress irrigations, while it was decreased in the others .Same findings were noticed when fat, ash and crude fiber were considered.

\section{Pasting properties of corn hybrids planted under water stress conditions}

Dough pasting properties of raw and nixtamalized SC 10 flours as well as nixtamalized corn hybrids were evaluated by RVA for peak viscosity, trough value, breakdown, final viscosity, and setback viscosity as presented in Table 2. Nixtamalization process largely decreased all measured RVA parameters, except peak time. Also, the results showed wide variation in RVA profiles of nixtamalized corn hybrids flour planted under drought condition. For instance, the peak viscosity values ranged from 230 to $529 \mathrm{cP}$ for genotypes No 5 and No 1, respectively. Also, as we can see from the same table, noteworthy low values of breakdown, final, and setback viscosities of flour prepared from genotype No 5 were obtained. Setback value of nixtamalized corn flour ranged from 209 to $489 \mathrm{cP}$ as compared to 2258 cP for the raw flour.

Table 1 Chemical composition of corn varieties planted under normal and drought condition (\% on dry weight basis)

\begin{tabular}{|c|c|c|c|c|c|}
\hline Hybrids & Protein & Fat & Ash & Fiber & Carbohydrate \\
\hline \multicolumn{6}{|c|}{ White corn hybrids planted under normal conditions } \\
\hline SC10 & $10.62^{\mathrm{EF}} \pm 0.17$ & $4.90^{B C} \pm 0.13$ & $1.75^{\mathrm{A}} \pm 0.05$ & $3.05^{\mathrm{CDE}} \pm 0.08$ & $79.68 \pm 1.65$ \\
\hline 1 & $11.62^{B} \pm 0.11$ & $4.30^{\mathrm{E}} \pm 0.05$ & $1.19^{\mathrm{D}} \pm 0.16$ & $3.16^{\mathrm{AB}} \pm 0.01$ & $79.73 \pm 1.80$ \\
\hline 2 & $12.03^{\mathrm{A}} \pm 0.21$ & $3.95^{\mathrm{F}} \pm 0.07$ & $1.35^{\mathrm{CD}} \pm 0.09$ & $3.19^{\mathrm{A}} \pm 0.02$ & $79.48 \pm 1.20$ \\
\hline 3 & $11.65^{B} \pm 0.15$ & $4.50^{\mathrm{D}} \pm 0.03$ & $1.65^{\mathrm{AB}} \pm 0.03$ & $2.90^{F} \pm 0.01$ & $79.30 \pm 1.18$ \\
\hline 4 & $12.08^{\mathrm{A}} \pm 0.17$ & $4.20^{\mathrm{E}} \pm 0.06$ & $1.29^{\mathrm{CD}} \pm 0.06$ & $2.95^{F} \pm 0.03$ & $79.48 \pm 1.70$ \\
\hline 5 & $11.35^{\mathrm{CB}} \pm 0.13$ & $4.30^{\mathrm{E}} \pm 0.07$ & $1.37^{B C D} \pm 0.08$ & $3.15^{A B C} \pm 0.09$ & $79.83 \pm 2.05$ \\
\hline 6 & $10.79^{\mathrm{DE}} \pm 0.15$ & $4.60^{\mathrm{D}} \pm 0.09$ & $1.55^{\mathrm{ABC}} \pm 0.01$ & $3.11^{A B C} \pm 0.05$ & $79.95 \pm 1.19$ \\
\hline \multicolumn{6}{|c|}{ White corn hybrids planted under water stress conditions } \\
\hline SC10 & $11.58^{B} \pm 0.11$ & $5.20^{\mathrm{A}} \pm 0.11$ & $1.52^{\mathrm{ABC}} \pm 0.15$ & $3.08^{\mathrm{BCD}} \pm 0.05$ & $78.62 \pm 1.40$ \\
\hline 1 & $11.06^{\mathrm{CD}} \pm 0.12$ & $4.50^{\mathrm{D}} \pm 0.10$ & $1.33^{\mathrm{CD}} \pm 0.02$ & $2.90^{F} \pm 0.10$ & $80.21 \pm 1.13$ \\
\hline 2 & $10.57^{\mathrm{EF}} \pm 0.23$ & $5.13^{\mathrm{A}} \pm 0.09$ & $1.20^{\mathrm{D}} \pm 0.03$ & $3.09^{A B C D} \pm 0.06$ & $79.88 \pm 1.10$ \\
\hline 3 & $10.99^{D} \pm 0.29$ & $5.05^{\mathrm{AB}} \pm 0.19$ & $1.20^{\mathrm{D}} \pm 0.08$ & $3.06^{\mathrm{BCD}} \pm 0.05$ & $79.70 \pm 1.40$ \\
\hline 4 & $12.11^{\mathrm{A}} \pm 0.39$ & $3.95^{F} \pm 0.11$ & $1.17^{\mathrm{D}} \pm 0.07$ & $3.08^{B C D} \pm 0.07$ & $79.69 \pm 1.50$ \\
\hline 5 & $10.44^{\mathrm{EF}} \pm 0.28$ & $4.25^{\mathrm{E}} \pm 0.13$ & $1.56^{\mathrm{ABC}} \pm 0.03$ & $3.12^{\mathrm{ABC}} \pm 0.11$ & $80.63 \pm 1.70$ \\
\hline 6 & $10.39^{F} \pm 0.22$ & $4.80^{C} \pm 0.15$ & $1.53^{\mathrm{ABC}} \pm 0.10$ & $3.00^{\mathrm{DEF}} \pm 0.03$ & $80.28 \pm 1.55$ \\
\hline LSD & 0.3515 & 0.1786 & 0.2997 & 0.1048 & NS \\
\hline
\end{tabular}


Table 2 Pasting properties of corn flour planted under drought condition

\begin{tabular}{|c|c|c|c|c|c|c|}
\hline Samples & Peak time (Min) & Peak viscosity (cP) & Trough viscosity $(C P)$ & Breakdown $(c P)$ & Final viscosity $(\mathrm{CP})$ & Setback (cP) \\
\hline Raw SC10 & 5.3 & 4274 & 2753 & 1521 & 4326 & 2258 \\
\hline \multicolumn{7}{|c|}{ Nixtamalized corn flour } \\
\hline SC10 & 7.0 & 277 & 224 & 53 & 480 & 256 \\
\hline 1 & 7.0 & 529 & 430 & 99 & 919 & 489 \\
\hline 2 & 7.0 & 420 & 340 & 80 & 729 & 389 \\
\hline 3 & 7.0 & 392 & 324 & 68 & 712 & 388 \\
\hline 4 & 7.0 & 331 & 264 & 67 & 536 & 272 \\
\hline 5 & 7.0 & 230 & 182 & 48 & 391 & 209 \\
\hline 6 & 7.0 & 435 & 347 & 88 & 776 & 429 \\
\hline
\end{tabular}

SC10 Single Cross Giza 10

\section{Physical properties of gluten-free biscuits}

Baking quality of gluten-free biscuits made from different hybrids of corn flours are shown in Table 3. The results indicated that there were significant differences in diameter and thickness of biscuit between samples made from raw corn flour and those made from NCF. While, there were no significant differences in both parameters between all biscuit samples made from nixtamalized corn flour. The biscuits made from raw SC10 flour had the lowest value of diameter and the highest thickness (3.52 and $1.18 \mathrm{~cm}$, respectively), while they ranged from 3.80 to 3.98 and from 0.65 to $0.70 \mathrm{~cm}$, respectively for biscuits made from nixtamalized corn flours. On contrary, the biscuits made from raw SC10 flour had the lowest value of spread ratio (4.14), while genotype no 3 gave the highest value of spread ratio (6.0).

Hunter parameters $\left(L^{*}, a^{*}\right.$, and $\left.b^{*}\right)$ of biscuit samples made from different corn hybrids are given in Table 3 and its photographs are presented in Fig. 1. The results showed significant differences $(p<0.05)$ in the color parameters of biscuit samples. The surface of biscuits made from raw SC10 and hybrid No. 3 flours were characterized by the highest and the lowest $L^{*}$ value (76.26 and 70.12, respectively). On contrary, biscuits made from hybrid No. 3 presented the highest $a^{*}$ value (8.75), while biscuit made from hybrid No. 4 was the yellowest one $\left(b^{*}=39.89\right)$.

\section{Sensory properties of gluten-free biscuits}

Organoleptic characteristics (color, texture, odor, taste, appearance, and overall acceptability) of gluten-free biscuits manufactured using corn flour of the tested hybrids were evaluated and the data are presented in Table 4. The results showed that there were significant differences $(p<0.05)$ between biscuit samples. It was clear that biscuit manufactured using raw SC10 flour was rated significantly lower by panelists in all sensory scores when compared to those manufactured using NCF. Also, it was noticed that biscuits made from NCF of hybrid No. 5 had significant higher acceptability in terms of texture (8.8), odor (9.1), taste (8.6), appearance (8.9), and overall acceptability (8.8). While, biscuit made from hybrid No. 3 recorded the highest color score (8.8). The organoleptic characteristics for biscuit manufactured

Table 3 Physical properties of biscuit made from corn flour planted under drought condition

\begin{tabular}{|c|c|c|c|c|c|c|}
\hline \multirow[t]{2}{*}{ Samples } & \multicolumn{3}{|l|}{ Baking quality } & \multicolumn{3}{|c|}{ Color attributes } \\
\hline & Diameter (cm) & Thickness (cm) & Spread ratio & $L^{*}$ & $a^{*}$ & $b^{*}$ \\
\hline Raw SC10 & $3.52^{B}$ & $1.18^{\mathrm{A}}$ & $2.98^{C}$ & $76.26^{A}$ & $5.50^{\mathrm{E}}$ & $33.17^{\mathrm{F}}$ \\
\hline \multicolumn{7}{|c|}{ Nixtamalized corn flour } \\
\hline SC10 & $3.95^{\mathrm{A}}$ & $0.68^{\mathrm{B}}$ & $5.81^{\mathrm{AB}}$ & $74.69^{\mathrm{A}}$ & $5.3^{F}$ & $32.41^{\mathrm{F}}$ \\
\hline 1 & $3.80^{\mathrm{A}}$ & $0.68^{\mathrm{B}}$ & $5.59^{B}$ & $72.79^{B}$ & $6.42^{c}$ & $36.49^{c}$ \\
\hline 2 & $3.85^{\mathrm{A}}$ & $0.67^{\mathrm{B}}$ & $5.75^{A B}$ & $75.01^{\mathrm{A}}$ & $5.24^{F}$ & $35.66^{\mathrm{D}}$ \\
\hline 3 & $3.90^{\mathrm{A}}$ & $0.65^{\mathrm{B}}$ & $6.00^{\mathrm{A}}$ & $70.12^{c}$ & $8.75^{\mathrm{A}}$ & $38.87^{\mathrm{B}}$ \\
\hline 4 & $3.90^{\mathrm{A}}$ & $0.70^{B}$ & $5.57^{\mathrm{B}}$ & $71.52^{B C}$ & $7.76^{\mathrm{B}}$ & $39.89^{\mathrm{A}}$ \\
\hline 5 & $3.98^{\mathrm{A}}$ & $0.70^{B}$ & $5.69^{\mathrm{AB}}$ & $74.9^{\mathrm{A}}$ & $5.62^{\mathrm{E}}$ & $34.00^{\mathrm{E}}$ \\
\hline 6 & $3.89^{\mathrm{A}}$ & $0.70^{B}$ & $5.56^{\mathrm{B}}$ & $75.02^{\mathrm{A}}$ & $5.79^{\mathrm{D}}$ & $34.91^{\mathrm{D}}$ \\
\hline LSD & 0.2686 & 0.0574 & 0.3841 & 1.5973 & 0.1409 & 0.7776 \\
\hline
\end{tabular}

SC10 Single Cross Giza 10 


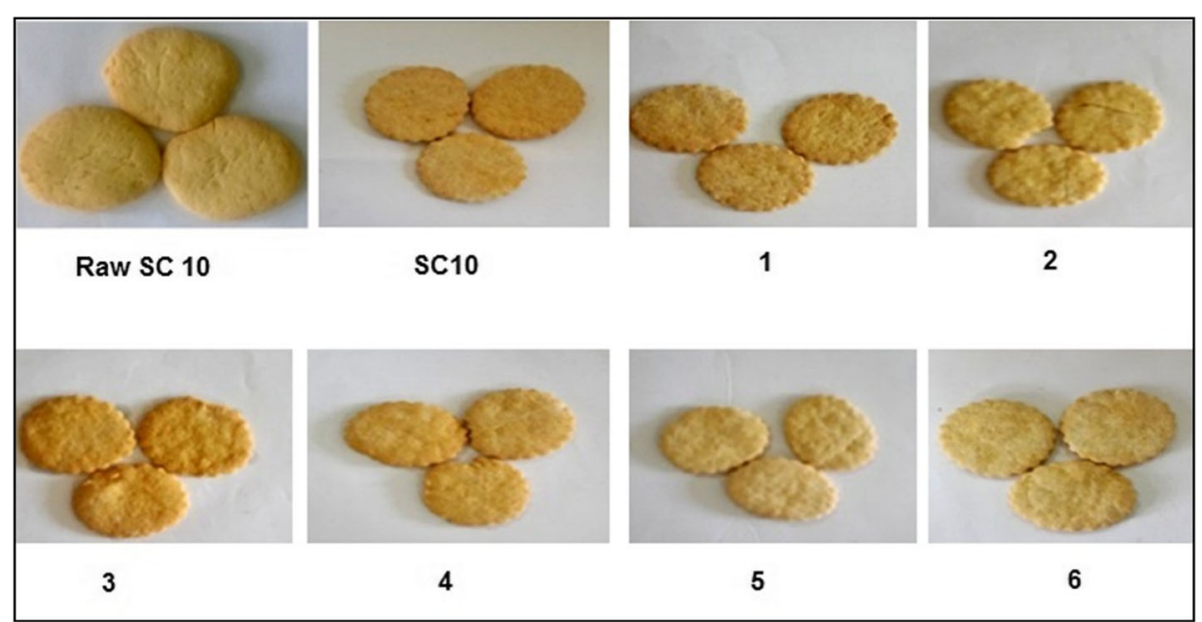

Fig. 1 Photographs of biscuits processed from corn flour planted under drought condition

using NCF of hybrids No. 5 and 2 were not significantly different but differed significantly when compared to those manufactured using NCF of other hybrids.

\section{Discussion}

High protein, fat, and carbohydrates yielding genotypes under water stress condition could be due to the drought tolerance genotypes. Also, the significant differences in proximate composition among various genotypes indicate existence of genetic variations and possible selection of favorable genotypes. The values of proximate composition were consistent with those reported by Sumbo and Victor (2014) and Qamar et al. (2017). They reported that white corn flours contained 9-15\% moisture, $1.4-2.6 \%$ ash, $7.82-12.02 \%$ protein, $0.95-2.01 \%$ crude fiber, and $65.38-78.74 \%$ total carbohydrates. On the other hand, Ergin and Herken (2012) reported lower values for moisture (6.65\%), ash (0.48\%), and protein $(4.54 \%)$ contents in white corn flour, while Oladapo et al. (2017) reported higher fat value (12.9\%).
Nixtamalization process largely decreased all measured RVA parameters, except peak time. Similar trend was observed by Mendez-Montealvo et al. (2007), as they reported that nixtamalized corn flour has a lower peak viscosity than raw flour, but the viscosity was obtained at a higher temperature. They attributed this result to the solubilization of amylose chains during nixtamalization, thus decreasing their contribution to increase in viscosity. The peak viscosity value illustrates the capacity of starch to absorb water and swelling of granules. The higher value of genotype No. 1 could be due to its higher amylopectin content which makes starch granule stronger and maintain its integrity, so it could swell bigger and has increased peak viscosity (Farasara et al. 2014). In general, our results showed that nixtamalization caused corn flour to have lower tendency to retrograde. Corn flour with the lowest tendency to retrograde was the one produced from genotype No. 5. While, flour form genotype No. 1 hydrated quickly to produce high peak viscosities and dispersed starch molecules during shear

Table 4 Organoleptic characteristics of biscuit from corn flour planted under drought condition

\begin{tabular}{|c|c|c|c|c|c|c|}
\hline Samples & Color (10) & Texture (10) & Oder (10) & Taste (10) & Appearance (10) & Overall acceptability (10) \\
\hline Raw SC10 & $6.0^{\mathrm{D}}$ & $6.2^{D}$ & $6.5^{\mathrm{D}}$ & $6.1^{\mathrm{D}}$ & $6.0^{D}$ & $5.9^{D}$ \\
\hline \multicolumn{7}{|c|}{ Nixtamalized corn flour } \\
\hline SC10 & $6.4^{c}$ & $7.9^{C}$ & $8.2^{c}$ & $7.7^{c}$ & $8.0^{C}$ & $7.9^{C}$ \\
\hline 1 & $8.2^{B}$ & $7.8^{c}$ & $8.1^{c}$ & $7.6^{c}$ & $7.9^{c}$ & $7.8^{c}$ \\
\hline 2 & $8.0^{\mathrm{B}}$ & $8.7^{\mathrm{A}}$ & $9.0^{\mathrm{A}}$ & $8.5^{\mathrm{A}}$ & $8.8^{A}$ & $8.7^{\mathrm{A}}$ \\
\hline 3 & $8.8^{\mathrm{A}}$ & $8.3^{B}$ & $8.6^{\mathrm{B}}$ & $8.1^{\mathrm{B}}$ & $8.4^{B}$ & $8.3^{\mathrm{B}}$ \\
\hline 4 & $8.3^{B}$ & $7.9^{C}$ & $8.2^{c}$ & $7.7^{c}$ & $8.0^{c}$ & $7.9^{c}$ \\
\hline 5 & $6.5^{c}$ & $8.8^{\mathrm{A}}$ & $9.1^{\mathrm{A}}$ & $8.6^{\mathrm{A}}$ & $8.9^{\mathrm{A}}$ & $8.8^{\mathrm{A}}$ \\
\hline 6 & $6.3^{D}$ & $7.9^{c}$ & $8.2^{c}$ & $7.7^{c}$ & $8.0^{C}$ & $7.9^{C}$ \\
\hline LSD & 0.3343 & 0.3631 & 0.3693 & 0.3497 & 0.3652 & 0.3615 \\
\hline
\end{tabular}

SC10 Single Cross Giza 10 
thinning, which then become highly aligned and could therefore result in gels that had increased stability, as indicated by high final and setback viscosities.

Baking quality of biscuits, such as diameter, thickness, and spread ratio, were significantly affected by the nixtamalization process. The diameter of biscuit samples made from NCF increased compared to the control. It has been reported that decreasing dough viscosity results in high flow rate (spread rate) of the dough and contributes to large diameter of produced biscuits. Also, the decrease in the thickness of nixtamalized flour biscuits could be due to the decreased dough viscosity (Makinde and Taibat 2018). Spread ratio is the result of both diameter and thickness and affects the texture and eating quality of the biscuits. Biscuit having higher spread ratio are considered the most desirable (Ahmed et al. 2016).

Color of biscuits is the first parameter perceived by the consumer and affects its acceptability. The development of brown color in biscuits crust is the result of both Maillard and caramelization reactions. Caramelization, which is the direct degradation of sugars at temperature above $150{ }^{\circ} \mathrm{C}$ (Zanoni et al. 1995), being occurred at the surface of baked products as the temperature exceeds this value (Hadiyanto et al. 2007). Maillard reaction is affected by various factors including proteins chemical conformation and presence of amino acid and reducing sugars as well as complex carbohydrates such as starch (Chung et al. 2012). Regarding that, the variations in biscuits color could be due to the varietal differences in these factors. Generally, the obtained values are similar to those reported by PerezCarrillo et al. (2017). Also, the mean values of spread ratio in our biscuits about (5.6) are comparable to that of Ahmed and Hussein (2014) and Rai et al. (2014).

The texture of biscuits evaluated by panelists related to pasting properties determined with the RVA (Table 2). Also, the color results were further supported by Hunter lab results (Table 3). These results are comparable to those obtained by Perez-Carrillo et al. (2017) as they reported that cookies manufactured from nixtamalized corn flour containing pregelatinized cross-linked corn starch were yielded gluten-free cookies with the highest level of sensory acceptability even better when compared to cookies made from refined wheat flour.

\section{Conclusion}

Based on the previous results, it could be concluded that: First, NCF obtained from all different hybrids of white corn planted under water stress conditions could be used for production of gluten-free biscuits for celiac patients with good acceptance quality. Second, biscuits samples which were made from genotypes No. 2 and 5 seems to be superior for sensory characteristics.
Abbreviations

CD: Celiac disease; NCF: Nixtamalized corn flour; RVA: Rapid visco analyser; SC10: Single Cross Giza 10

\section{Acknowledgment}

The authors gratefully acknowledge Prof. Dr. Abdel-Sattar Ahmed Abdel-Star who presented the main field experiments.

\section{Authors' contributions}

The authors contributed to field experimentation, data collection, conducting research analysis, and participating in writing the manuscript. All authors read and approved the final manuscript.

\section{Funding}

The authors gratefully thank the National Research Centre (Egypt) fund (project no, 1020105) for their financial support to this work.

\section{Availability of data and materials}

All data generated or analyzed in this study are included in this published article.

\section{Ethics approval and consent to participate}

Not applicable.

\section{Consent for publication}

Not applicable.

\section{Competing interests}

The authors declare that they have no competing interests.

\section{Author details}

${ }^{1}$ Food Technology Department, National Research Centre, 33 Bohouth St., Dokki, Cairo, Egypt. ${ }^{2}$ Genetics and Cytology Department, National Research Centre, 33 Bohouth St., Dokki, Cairo, Egypt.

Received: 14 April 2019 Accepted: 4 February 2020

Published online: 14 February 2020

\section{References}

AACC. Approved Methods of the American Association of Cereal Chemists. 10th ed. St Paul Minnesota; 2000.

Ahmed MAH, Mustafa Al, Hussan HAR, Elfaki AE (2016) Proximate composition, protein digestibility, starch digestibility, physical properties and sensory evaluation of decorticated sorghum and maize biscuits supplemented with chickpea flour. Int J Curr Res Aca Rev. 4:1-11

Ahmed ZS, Hussein AMS (2014) Exploring the suitability of incorporating tiger nut flour as novel ingredient in gluten-free biscuit. Polish J Food Nutr Sci. 64:27-33

AOAC (2005) Official Methods of Analysis for protein. Association of Official Analytical Chemists, 18th edn. North Fredric avenue Gaithersburg, Maryland Arlington

Bernardo D, Pena AS (2012) Developing strategies to improve quality of life of patients with gluten intolerance in patients with and without celiac disease. Eur J Int Med. 23:6-8

Chavez-Santoscoy RA, Gutierrez-Uribe JA, Serna-Saldivar SO, Perez-Carrillo E (2016) Production of maize tortillas and cookies from nixtamalized flour enriched with anthocyanins, flavonoids and saponins extracted from black bean (Phaseolus vulgaris) seed coats. Food Chem. 192:90-97

Chung SY, Han SH, Lee SW, Rhee C (2012) Effect of Maillard reaction products prepared from glucose-glycine model systems on starch digestibility. Starch. 64:657-664

Ergin A, Herken EN (2012) Use of various flours in gluten-free biscuits. J Food Agric Environ. 10:128-131

Esmail RM, Abdel-Sttar AA, El-Mouhamady AA, Abdelgany EM, Fathallaha FB (2016) Assessment of genetic parameters and drought tolerance indices in maize double cross. Res J Pharm Biol Chem Sci. 7:2409-2428

Esmail RM, Hussein AMS, Abdelmaguid NM (2015) Influence of water stress on yield, technological and rheological characteristics of some new wheat lines. Res J Pharm Biol Chem Sci. 6:840-854

FAO. Food and Agricultural Organization of the United Nations FAOSTAT Database; 2009. http://faostat.fao.org. Acceded 4 Apr 2018. 
Farasara R, Hariyadi P, Fardiaz D, Dewanti-Hariyadi R (2014) Pasting properties of white corn flours of anoman 1 and pulut harapan varieties as affected by fementation process. Food Nutr Sci. 5:2038-2047

Gomez MH, Waniska RD, Rooney LW (1991) Starchch aracterization of nixtamalized corn flour. Cereal Chem J. 68:578-582

Hadiyanto H, Asselman A, Van Straten G, Boom RM, Esveld DC, Van Boxtel AJB (2007) Quality prediction of bakery products in the initial phase of process design. Innov Food Sci Emerg Technol. 8:285-298

Hoojjat P, Zabik ME (1984) Sugar-snap cookies prepared with wheat navy bean-sesame seed flour blends. Cereal Chem. 61:41-44

Ignjatovic-Micic D, Kostadinovic M, Bozinovic S, Andjelkovic V, Vancetovic J (2014) High grain quality accessions within a maize drought tolerant core collection. Sci Agric. 71:345-355

Makinde FM, Taibat AA (2018) Quality characteristics of biscuits produced from composite flours of wheat, corn, almondand coconut. Annals Food Sci Technol 19:216-225

Mendez-Montealvo G, Trejo-Espino JL, Paredes O, Bello-Perez LA (2007) Physicochemical and morphological characteristics of nixtamalized maize starch. Starch/Starke. 59:277-283

Oladapo AS, Adepeju AB, Akinyele AA, Adepeju DM (2017) The proximate, functional and anti-nutritional properties of three selected varieties of maize (yellow, white and pop corn) flour. Int J Sci Eng Sci. 1:23-26

Padalino L, Conte A, Del Nobile MA (2016) Overview on the general approaches to improve gluten-free pasta and bread. Foods. 87:1-18

Padalino L, Mastromatteo M, Sepielli G, Del Nobile MA (2011) Formulation optimization of gluten-free functional spaghetti based on maize flour and oat bran enriched in $\beta$-glucans. Material. 4:2119-2135

Perez-Carrillo E, Frias-Escobar A, Gutierrez-Mendívil K, Guajardo-Flores S, SernaSaldívar SO (2017) Effect of maize starch substitution on physicochemical and sensory attributes of gluten-free cookies produced from nixtamalized flour. J Food Process. 2017:1-6

Qamar S, Aslam M, Huyop F, Javed MA (2017) Comparative study for the determination of nutritional composition in commercial and noncommercial maize flours. Pak J Bot. 49:519-523

Rai S, Kaur A, Singh B (2014) Quality characteristics of gluten free cookies prepared from different flour combinations. J Food Sci Technol. 51:785-789

Sumbo AH, Victor IA (2014) Comparison of chemical composition, functional properties and amino acids composition of quality protein maize and common maize (Zea may L). Afr J Food Sci Technol. 5:81-89

Vidal-Quintanar RL, Love J, Johnson LA (2001) Role of oil on physical properties of corn masa flours and sensory characteristics of corn tortillas. J Food Process Preser. 25:1-14

Zanoni B, Peri C, Bruno D (1995) Modelling of browning kinetics of bread crust during baking. Lebens-Wissen Technol. 28:604-609

\section{Publisher's Note}

Springer Nature remains neutral with regard to jurisdictional claims in published maps and institutional affiliations.

\section{Submit your manuscript to a SpringerOpen ${ }^{\circ}$ journal and benefit from:}

- Convenient online submission

- Rigorous peer review

- Open access: articles freely available online

- High visibility within the field

- Retaining the copyright to your article

Submit your next manuscript at $\boldsymbol{\nabla}$ springeropen.com 